\title{
Eguzkitako kremen ekotoxizitatea
}

(Sunscreens ecotoxicity)

Ane Irakulis Arza*, Laura Saenz del Burgo

Farmazia Fakultatea, Euskal Herriko Unibertsitatea (UPV/EHU)

LABURPENA: Koralezko uharriak ur azpiko ekosistemarik dibertsoenetarikoak dira, ingurumeneko aldaketa txikiekiko sentikorrak direnak. Hala, urteetan zehar gizakiek eragindako mehatxu lokal zein mundu-mailakoek koralen heriotza eragin dute eta, horrekin batera, biodibertsitatearen murrizketa. Mehatxu lokalen artean, eguzkitako kremak daude, haien konposatua den oxibentzona barne. Iragazki organiko hori, azalaren babeserako ez ezik, azalaren eta ilearen zaintze-produktuetan, kosmetikarako eta perfumeen konposaketarako ere erabili izan da. Itsasoan sartzean, krema bertan murgildu, eta koraletan metatzen da, haien zuritzea eta ondoriozko heriotza eraginez. Konposatu horren eragin toxikoak azterturik, ekosistemaren babeserako alternatibak bilatu beharko dira, zink oxidoaren, titanio dioxidoaren eta horien gisako iragazki mineralen ezaugarriak baloratuz.

HITZ GAKOAK: ekotoxizitatea, koralezko uharriak, oxibentzona, titanio dioxidoa, zink oxidoa.

ABSTRACT: Coral reefs are one of the most diverse underwater ecosystems, sensitive to small changes in the environment. Thus, over the years both local and global threats have led to the death of corals and, in turn, an important reduction on biodiversity. Among local threats, there are sunscreens, including oxybenzone compound. This organic filter has been used not only for skin protection, but also for skin and hair care products, cosmetics and perfume. Upon entering the sea, suncreams are submerged and deposited in the corals, causing their bleaching and death. When examining the toxic effects of this compound, alternatives to ecosystem protection should be found, assessing the characteristics of mineral filters such as zinc oxide or titanium dioxide.

KEYWORDS: ecotoxicity, coral reefs, oxybenzone, titanium dioxide, zinc oxide.

\footnotetext{
* Harremanetan jartzeko / Corresponding author: Ane Irakulis Arza. Farmazia Fakultatea, Euskal Herriko Unibertsitatea UPV/EHU, Paseo de la Universidad, 7, 01006, Vitoria-Gasteiz, Araba. - irakulisane@gmail.com

Nola aipatu / How to cite: Irakulis Arza, Ane; Saenz del Burgo, Laura (2021). "Eguzkitako kremen ekotoxizitatea». Ekaia, 40, 2021, 109-133. (https://doi.org/10.1387/ekaia.21704).

Jasotze-data: 2020, maiatzak 4; Onartze-data: 2021, urtarrilak 7.

ISSN 0214-9753 - elSSN 2444-3581 / (c) 2021 UPV/EHU
}

(c) (i) $\odot$ Lan hau Creative Commons Aitortu-EzKomertziala-LanEratorririkGabe 4.0 Nazioartekoa lizentzia baten mende dago 


\section{SARRERA}

Koralezko uharriak zooide edo polipo deituriko animalia kolonialak dira, eta mikroalgekiko sinbiosian bizi dira; hauek fotosintesiaren bidez lorturiko energia ematen diete bizirauteko. Ur azpiko ekosistemarik baliotsu eta biologikoki dibertsoenetarikoak dira, itsaso tropikaletako sakonera gutxiko ur garbi eta epeletan sortzen direnak; landare eta algek fotosintesia egiteko, eta ur-korronteen bidez nutrienteak lortzeko baldintza optimoak baitira. Hala ere, aniztasun handiko ekosistema horiek inguruneko aldaketa txikiekiko sentikorrak dira [1].

Koralezko arrezife osasuntsuek habitata, elikadura eta erruteko tokia ematen dizkiete milaka itsas espezieri; zehazki, itsas ekosistemari dagokion $\%$ 25i. Halaber, mundu-mailan gutxi gorabehera bizi diren 500 milioi gizabanakori aukera ematen die elikatzeko, arrantzatzeko eta turismotik dirua lortzeko. Gainera, ekaitz, tsunami, uholde edo higaduren ondoriozko heriotzen prebentzioa eskaintzen dute, kostako azpiegiturari babesa emanez. Horrez gain, gaixotasunen tratamendurako medikamentu berri gisa erabil daitezke $[1,2]$.

Egindako hainbat ikerketatan, hamarkadetan zehar ozeanoek aireko tenperaturaren igoera erradikaletatik babestu gaituztela ondorioztatu da; berotegi-efektuko gasetan dagoen beroaren \% 93 xurgatu du, eta, horrela, aldaketa klimatikoaren eraginak gutxitu. Hori horrela, «koralezko arrezifeak gure ordez egosten ari direla» esan daiteke. Egun, munduko koralezko arrezifeen erdiak mehatxuan daude, eta horien kalteak ondorio negatibo larria dakar, mota askotariko aimaliei eragiten dielako: arrainak, itsas hegaztiak, belakiak, marmokak, harrak, ganbak, otarrainak, karramarroak, itsas izarrak, itsas trikuak, holoturia, dortokak eta sugeak barne [1].

Koralezko arrezifeen ekosistementzako mundu-mailako mehatxuen artean, ozeanoetako tenperatura-igoera eta ezaugarri kimikoen aldaketak (azidifikazioa) dira garrantzitsuenak: sinbiosian bizi diren eta koralei elikagaiak ematen dizkien mikroalgak galtzea eragiten dute, eta koraletan estresa. Mikroalgak gabe, koralek kolorea galdu, eta polipoen kaltzio karbonatozko aurretiko egitura zuria erakusten dute; ondorioz, koloniak hil, edo gaixotasun infekziosoekiko sentikorragoak bihur daitezke. Urtero, itsasoek fosil-jatorriko erregaiek (petrolioa, ikatza eta gas naturala) igorritako karbono dioxidoaren $\left(\mathrm{CO}_{2}\right)$ laurdena xurgatzen dute. Urarekin erreakzionatzean, azido karbonikoa sortu eta itsasoko azidotasuna igotzen da. Horrek koralek kaltzio karbonatozko egitura sortzeko beharrezkoak dituzten gatz eta ioi disolbatuen erabilgarritasuna murriztu dezake; ondorioz, koralen eta arrezifeen hazkundea ere bai. Azidifikazioa oso nabaria bada, koralen hezurdura disolbatu eta desager daiteke [3]. Industria-aroaren hasieratik itsasoko uraren pHa 0,1 jaitsi eta azidoagoa bihurtu dela behar da kontuan hartu [4]. 
Arrezifeek pairatzen dituzten mehatxu lokalen artean, hondamen edo eraso fisikoak daude: kostako garapenak, dragatzeak eta harrobi-eraketak sorturikoak; itsasontzien aingura edo oinarriek sortuak; edo aisialdi-helburuarekin erabilera desegokiak, hala nola koralak ukitzeak edo ateratzeak, sortuak. Gehiegizko arrantzak eta akuarioetan jartzeko zein bitxiak egiteko erabiltzeak ere koralezko arrezifeen suntsiketa eragiten dute. Lurrean sortu eta kostaldeko uretara heltzen den kontaminazioari dagokionez, hainbat eragile daude; besteak beste, kostako garapenarekin erlazionaturiko jalkitzea (ondoriozko asfixia), nutrienteak (nekazaritza-ongarri edo animali hondakinetako gehiegizko nitrogeno eta fosforoa), patogenoak (gaixotasunak eragiten dituzten bakterio eta parasitoak), hondakin eta mikroplastikoak (hondakinen kudeaketa desegokia, digestio-traktuko buxapena eraginez), eta substantzia toxikoak (adibidez, eguzkitako kremak, oxibentzona barne). Azken horiek dira lan bibliografiko honetan aztertuko diren konposatuak [3].

Estres-faktore horien guztien ondorioz, arrezifeen erresistentzia orokorra murriztu, eta gaixotasunekiko eta espezie inbaditzaileekiko sentikortasuna handitu daitezke; horrek ekosistemaren oreka biologikoari eragiten dio [3].

Eguzkitako kremen konposatuei dagokienez (mehatxuen artean aipatuak eurak), hainbat herrialdetan, eztabaidagai izan dute haien erabilera, koraletan duten eragina dela eta. Egungo helmuga turistikoetako asko arrezifezko koralak dituzten aldeak dira; Australiako Koral Hesi Handia, Hawaii, Birjina uharte eta Israeleko arrezifeak, besteak beste [5]. Ondorioz, eguzkitako kremekiko esposizio handiena pairatzeko arriskua dutenak dira bereziki sentikorrenak. Hori dela eta, oxibentzona eta oktinoxatoa bezalako konposatuek koraletan duten eraginaren inguruko hainbat ikerketa egin izan dira. Emaitzei erreparatuz, erregulazio espezifikoak beharrezkoak direla ondorioztatu da. Hori horrela, Hawaii da konposatu horien salmenta debekatzen duen legea sinatu duen lehen estatua; legea 2021eko urtarrilaren 1etik aurrera sartu da indarrean [6]. Bonaire eta Aruba irlek ere indarrean jarri dute legea, data berean. Hawaiiko estatuaren pausoei jarraituz, Palauko errepublikan 2020an abiaraziko da legea, munduko altxor preziatuenetarikoa babesteko asmoz [7]-[10].

Lege horiek oinarri hartuta, oxibentzona konposatuaren garrantzi toxikologikoa azpimarratu daiteke, eta, beraz, haren inguruko ikerketa bibliografikoa egitearen premia. Nahiz eta beste itsas organismoetan ere eragina izan, koralezko uharriek itsas ekosistemako biodibertsitate handiena daukaten egitura osatzen dute. Horregatik, eguzkitako kremek koraletan duten toxikotasuna ezagutuz, arrezifeen babesean eta ondorioz, itsas-ekosistema osoan lagundu ahalko da.

Berrikuspen bibliografiko honek bi helburu ditu. Helburu bat da kremen ohiko konposaketak gehienbat koralei eraginez itsas ekosisteman toxikotasuna nola sortzen duen aztertzea eta aldaketa klimatikoarekin daukan 
lotura balioztatzea; horretarako, gehien erabiltzen diren ultramore iragazkiak eta horien berezitasunak aztertuko dira.

Beste helburua da oxibentzona saihesteko alternatibak ematea eta konposatu hobeen ikerketa bibliografikoa egitea, arazoari aurre egin ahal izateko, eta, horrekin batera, populazioaren heziketari dagokion informazio-bilketa egitea, beharrezkoak izan daitezkeen ohitura-aldaketak nabarmenduz.

\section{METODOLOGIA}

Lan bibliografiko hau egiteko, PubMed eta «Google Academia» datu-baseak erabili dira; artikuluak bilatzeko, «sunscreens», «oxybenzone», «coral reefs», «titanium dioxide» eta «zinc oxide» eta gisako hitz-gakoak erabili dira. Ezarritako data-tartea 2010etik 2019ra bitartekoa izan da; hala ere, gai zehatz baten artikuluen bilaketan data zabalagoa erabili da. Artikuluen hizkuntza ingelesa da, eta guztira 41 dokumentu erabili dira (1. irudia). Horrez gain, iturri ezberdinetako informazioa bildu da, hala nola «National Geographic»ekoa, EPAkoa (United States Environmental Protection Agency) eta arrezifezko koralen inguruko hainbat erakundetakoa (ICRI, International Coral Reef Initiative, adibidez); artikuluak ingelesez zein gaztelaniaz zeuden idatzita.

\section{IDENTIFIKAZIOA}

Datu-baseetan bilatutako dokumentuak $(n=59) \quad$ Beste iturri batzuetako dokumentuak $(n=24)$

$\Downarrow$

\section{MIAKETA}

Bikoiztutako dokumentuak baztertu ondoren $(n=49)$

$\Downarrow$

Balioztatutako documentuak $(\mathrm{n}=49)$

$\Downarrow$

HAUTATZEA

Testu osoa duten artikuluak $(\mathrm{n}=43)$

$\Downarrow$

\section{LANEAN GEHITZEA}

Lanean gehitutako ikerketak $(n=41)$

1. irudia. Lanean gehitutako artikulu bilaketaren metodologiaren irudi eskematikoa. 


\section{OXIBENTZONAREN ERAGIN TOXIKO OROKORRAK}

Oxibentzona (BP-3 edo bentzofenona-3) norbanakoaren zaintze-produktuen (eguzkitako kremak, azal eta ilearen zaintze-produktuak, kosmetikako produktuak, perfumeak, etab.) konposaketan erabiltzen den hidrokarburo aromatikoa da. Iragazki organiko hori uhin laburreko (290$320 \mathrm{~nm}$ ) argi ultramorea (UVB) eta UVA izpiak (320-340 nm) xurgatzeko erabiltzen da. Eguzkitako kremen konposizioaren \% 6ko kontzentraziotik gora eta norbanakoaren zaintze-produktuen $\% 0$,5etik gora azaltzen da [11].

Kim eta Choik giza gernuan, serumean eta esnean aurkitu zuten: hartzaileekiko lotura entseguetan (ingelesez, receptor binding assays), eragin endokrino ez-desiragarriak erakutsi zituzten, aktibitate antiandrogeniko eta antiestrogenikoarekin batera [12]. Gainera, Huo eta kideek amaren oxibentzona esposizioaren eta Hirschsprung-en gaixotasunaren (HSCR) arteko erlazioa hauteman zuten. HSCR gaixotasuna deritzo gandor neuraletako zelulen migrazioan akatsa emateagatik jaioberrietan sortzen den heste-anormaltasunari; haurdunaldiko 5 eta 12 aste bitartean agertzen da. Gaixotasunaren eta BP-3aren kontzentrazioaren arteko erlazioa dosiaren mendekoa dela ondorioztatu zuten [13].

Oxibentzona lurzoruan, jalkinetan, lokatzean, biotan eta uretan detektatu da [12]. Larruazalean emandako eguzkitako kremen \% 25 inguru xurgatzen ez denez, soberakina urarekin batera joaten da krema eman eta 20 minuturen buruan uretara sartuz gero. Hala, kremen konposatuak, itsaso zein igerilekuetako urarekin kontaktuan jartzean, uretara igarotzen dira, eta bertan pilatzen [14]. Sherwood eta kideek kloroak oxibentzonarekin erreakzionatzean sortutako oxibentzona kloratua aztertu zuten, eta zelulen heriotza gehiago gertatzen direla ondorioztatu zuten [15]. Beste ikerlan batek oxibentzonaren klorazioaren ondoriozko aldaketa eta zinetika ebaluatu zituen. Emaitzek aldaketa genotoxikoaren produktu gehiago sortzen direla adierazi zuten, nahiz eta konposatua ezabatu, edateko uretan arriskua egon daitekeela suposatuz [16].

Aldi berean, gizakiarentzat narritagarria izateaz gain, BP-3a itsas ingurumenaren kutsatzaile garrantzitsua da (2. irudia). Urteetan zehar, ikertzaile asko ozeanoetan sartutako eguzkitako krema kantitatea balioztatzen saiatu dira. 2015ean argitaratutako ikerketa batean, urtean 6.000 eta 14.000 tona bitarte askatzen dira koralezko arrezifeak dauden guneetan, horiek baitira helmuga turistiko ohikoenak uda-sasoian. Produktu gehienek beren osagaietan oxibentzona \% 1-10eko ehunekoan daukatela kontuan hartuta, eragin toxikoak larriak izan daitezkeela ondoriozta daiteke [17]. 


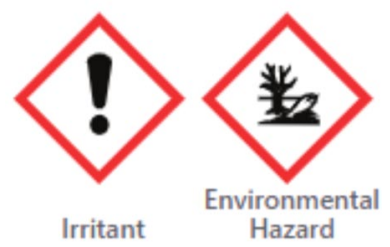

2. irudia. GHS (Globally Harmonized System) arautegiaren arabera oxibentzonari dagozkion piktogramak [18].

\subsection{Oxibentzonaren eragin toxikopatologikoak koraletan}

Hawaii eta Birjina uharte estatubatuarretan BP-3aren eragin toxikopatologikoak ikertzeko asmoz, Downs eta kideek Stylophora pistillata koralaren larbetan eta kultibatutako zelula primarioetan zituen eraginak argitaratu zituzten. Koralen planula larben morfologia baldintza kontrolatuetan pepino-itxurakoa da, zooxantela mikroalga errenkadatan antolatuta duena. Planulak mugimendu ia konstantean daude, gorputz luzanga estaltzen duten zilioek bultzatuta. Planularen hazkuntza edo morfologia aldatzen bada, koralaren bizi-zikloan ere aldatzen da [17].

BP-3a agente fototoxikatzailea da, eta toxikotasun ezberdina eragiten du argitan edo ilunetan egotearen arabera. Hala, ezaugarri fototoxikatzailearen ondorioz eragin ez-desiragarriak argiarekin nabarmentzen direla ondorioztatu zen. Argitan zein ilunetan lau orduz BP-3aren eraginpean egonda, zilioen mugimenduaren murrizketa eta morfologiaren aldaketa adierazgarriak ikusi ziren. Egun eguzkitsu bateko argi-mailak $2000 \mu \mathrm{mol} /$ $\mathrm{m}^{2} / \mathrm{s}$ baino altuagoko erradiazio aktibo fotosintetikoa du, egindako ikerketan baino 5 aldiz altuagoa dena. Hala ere, egungo ingurumen-baldintzak aldatzen ari direla eta hainbat faktoreren mende dagoela kontuan hartu behar da [17].

Zooxantela nabarmenki gutxiago detektatu ziren BP-3 228 $\mu \mathrm{g} / \mathrm{L}$ kontzentrazioan. Argitan BP-3aren eraginpean jartzeak zooxantela algaren lesio zuzena eragin zuen. Hori gertatzearen interpretaziorik probableena mintz tilakoidea osatzen duten egitura molekularren estres fotooxidatiboaren induzioa da. Ilunpean, ordea, koralen zuritze-fenomenoa zooxantela sinbiotikoaren sinbiofagiaren ondorioz izan zen, hau da, koralaren zelula gastrodermalek zooxantela «digeritzearen» ondorioz. Gainera, erantzun zelular menderatzailea autofagia izanik, zelula mota guztietan mikroautofagosomak ugariagoak eta bakuolatutako gorputzak luzeagoak ziren. Erantzun horren alderdi bereizgarriena mintz bikoitz nuklearraren bereizketa izan zen, zelularen heriotza autofagikoaren ezaugarri klasikoa dena [17]. 
BP-3a koralentzako genotoxikoa da, eta eragina argiarekin areagotzen da. DNA apirimidinikoaren (DNA AP) lesioak elkarrekintza oxidatiboari edo alkilazioei erantzunez gerta daitezke. DNAren kalteen pilaketak, koralen biltzean eta koral gazteen bizirauteko aukeretan eragina izateaz gain, ugalketarako esfortzuan eta batera mantentzearen arrakastan ere eragina du. Oxibentzonaren eraginetik onik ateratako planulak finkatu, eraldatu eta heldu kolonialetan eraldatu daitezke, baina agente estresatzaileei, hala nola itsasoko gainazalaren tenperatura igoerari, aurre egiteko zailtasunak izaten dituzte. Koraletako larbentzat, 139 eta 3100 ppb bitarteko kontzentrazio letal 50 (LC50) zehaztu zuten [17].

Oxibentzonaren esposizioaren ondoriozko planularen osifikazioa garapen endokrinoaren asalduraren kasurik arraroenetarikoa da. Ornodunen fisiologiari erreparatuz, estrogenoek, osifikazioan eta eskeletoaren mantenuan duten funtzioa dela eta, hezurren anabolismo eta katabolismoan izaten dute eragina. Hala, estrogeno-kontzentrazio altuetan eskeletoaren hiperosifikazioa jazo daiteke. Disruptore endokrino «klasikoekin» (tributiltina eta dioxina, adibidez), osifikazioa inhibituta dago. Bentzofenonek, ordea, estrogeno eta hartzaile aril hidrokarburoetan kontrako eraginak erakutsi zituzten: markatzaile estrogeniko «klasikoetatik» kanpo sailkatutako disrupzio endokrinoa induzitu zuten. Planularen osifikazioa neurtzeko metodo ezberdinak erabili ziren: alizarin tindaketa eta kalzeina (fluorexona) fluoreszentzia, besteak beste [17].

\section{EGUZKITAKO KREMEN ERAGIN ZURITZAILEA KORALETAN}

Koralen zuritzea deritzo koralekiko sinbiosian bizi diren eta kolorea zein elikagaiak ematen dizkien zooxantela (latinez zooxanthellae) mikroalgak galtzeari. Arazo horren jatorri nagusia aldaketa klimatikoa da, Lurreko tenperatura igotzean ozeanoa ere berotzen baita. Koralek, aldaketa txikiekiko sentikorrak direnez, estresatu, eta mikroalgak kanporatzen dituzte, eta duten kolorea galtzen. Tenperaturak altu mantenduz gero, koralak hil daitezke; hala ere, ez da zertan beti gertatu, baina gerta daitekeelako eta arriskuan dagoelako seinale garbia da [19].

Tenperatura-aldaketaz gain, UV irradiazio altuak, konposatu kutsatzaileak eta gaixotasun bakterianoak ere koralen zuritzearekin erlazionaturik daude. Danovaro eta al. lehenak izan ziren oxibentzonak (beste konposatu batzuekin batera) koralean duen eragin zuritzailea deskribatzen. Hainbat herrialdetako Acropora, Stylophora pistillata eta Millepora complanata koral-espezieak aztertu ziren, eguzkitako kremen 10,33, 50 eta $100 \mu \mathrm{L} / \mathrm{L}$ itsasoko ur-kontzentrazioak aplikatuz. In situ egindako ikerketak TEMaren (Transmision Electron Microscopy) eta epifluoreszentziaren bidez neurtu ziren [14]. 
$100 \mu \mathrm{L}$ eguzkitako kremaren eragina tenperatura ezberdinetan (28 eta $30{ }^{\circ} \mathrm{C}$ ) aztertzeko, Acropora divaricata koralaren noduluak 24 orduz inkubatu ziren. Horien arteko ezberdintasunak aztertuz, zuritzea tenperatura altuagoan azkarrago gertatzen dela ondorioztatu zen; horrek eragin sinergikoa azaldu zuen (3. irudia). Bi tenperaturaren arteko aldea $\left(2{ }^{\circ} \mathrm{C}\right)$ txikia dela kontuan harturik, kolore-aldaketa oso nabaria dela ikus daiteke. Tratatutako koraletatik askaturiko mikroalgen pigmentu fotosintetikoak eta mintzaren osotasunaren galera TEMaren eta epifluoreszentziaren bidez aztertu ziren; eguzkitako kremek duten eragin zuritzailea nabarmendu zen [14].
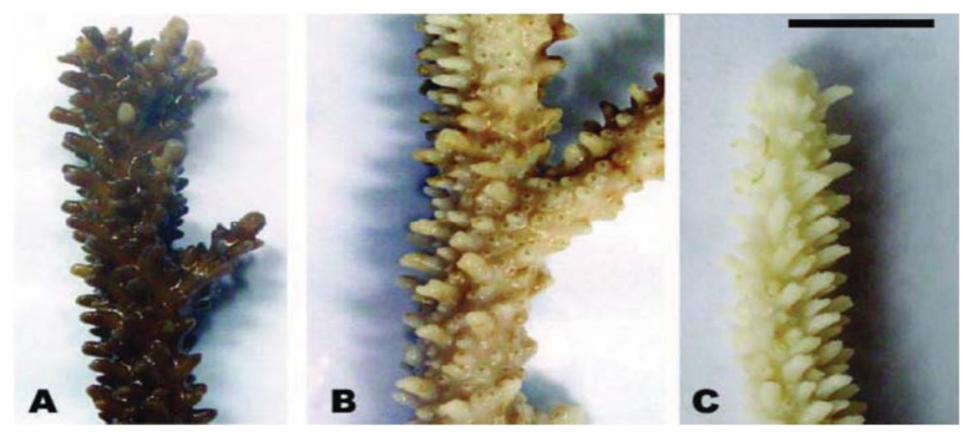

3. irudia. Eguzkitako kremen $100 \mu \mathrm{L}$ kontzentrazioak A. divaricataren noduluetan duen eragina kontrolarekin konparatuz (A) eta tenperatura ezberdinetan, $28^{\circ} \mathrm{C}$ (B) eta $30^{\circ} \mathrm{C}$ (C) [14].

Eguzkitako kremek normalean 20 konposatu baino gehiago izaten dituztenez, horietatik 7 aukeratu eta aztertu ziren, BP-3a barne. Datuen artean hau lortu zen: konposatuen gehienek, 33 eta 50 ppm-ko kontzentrazioetan egonik, koralen zuritzea eta heriotza eragin zuten. Oxibentzonak, beste osagai batzuekin batera, aztertutako koraletan erabateko zuritzea eragiten duela erakutsi zuen, nahiz eta erabilitako kontzentrazioak baxuak izan $(10 \mu \mathrm{g} / \mathrm{L})$. Indiako Ozeanoan egindako bi ikerketatan (Itsaso Gorrian eta Andamango itsasoan), oxibentzonak, 33 eta $50 \mathrm{ppm}$ kontzentrazioetan, hurrenez hurren, 24 eta 48 ordura erakutsi zuen eragin zuritzailearen hasiera. Gainera, 48 eta 96 ordura, \% 86 eta $\%$ 93ko zuritze-tasak eta \% 83-84ko zooxantelaren askapen-tasak lortu ziren [14].

Bestalde, eguzkitako kremek infekzio birikoetan duten eragina TEM analisien bidez aztertu zuten; eta zooxantela barruan eta inguruan birus antzeko partikulen (VLP) presentzia detektatu. Horrela, birusen infekzio lisogenikoak areagotzen direla (prokariotoen ziklo litikoak, eukariotoen in- 
fekzio latenteen baliokideak) eta zuritze-fenomenoa tenperatura altuetan azkarrago gertatzen dela ondorioztatu zuten. Birusek gene-transferentzia horizontalean eta itsas ekosistemen energia zein materialak lortzeko bidean duten eragina kontuan hartuta, ziklo biogeokimiko orokorretan inplikazio garrantzitsuak dituzte. Bestalde, pestizidek, hidrokarburoek eta bestelako kutsatzaileek eguzkitako kremekin eragin sinergikoa izan dezaketela uste da; horrek koralen zuritzea areagotzen du [14].

Hurrengo hamarkadetan ozeanoaren azidotzearen eta tenperatura-igoeraren eragin sinergikoagatik koralen zuritzea nabarmenki igoko dela uste da [20]. Arazoaren larritasuna nabarmentzeko, 2005ean Amerikako Estatu Batuek arrezifeen erdiak galdu zituen Karibeko arrezifeen zuritze masiboaren ondorioz [21].

\section{BIOMETAKETA ETA BIOMAGNIFIKAZIOA}

Urarekiko, elikagaiekiko eta sedimentuekiko esposizio konbinatuagatik organismo batean gertatzen den produktu kimiko baten metaketa garbiari biometaketa deritzo. Hala, elikadura katean gorenen kokatuta dauden espezieek produktu kimiko guztiekin kontaktuan egoteko aukera gehiago dituzte (biomagnifikazioa). Biometaketa-ereduak produktu horien biomagnifikazioa hobeto ulertzeko tresna erabilgarriak dira. Iragazki ultramore gehienak, lipofilikoak diren heinean (uretan disolbagarritasun baxua), biotan eta gizakietan metatu, eta konposatuen pilaketa metabolizazio- edo iraizketa-prozesuak baino azkarrago eman daiteke [22].

UV iragazkien biometaketari buruz ikertzen lehenak Tsui eta taldea izan ziren; horretarako, 7 iragazki organiko eta 5 koral-espezie (62 lagin) aztertu zituzten. Lau aldetan eta sasoi ezberdinetan (hezea eta lehorra) lortutako kontzentrazio ezberdintasunak balioztatu, eta koraletako ehunen biometaketa-faktoreak (BAF) zehaztu zituzten [20].

Koral-laginen \% 20k gainditu zuten, gutxi gorabehera, larbaren formaanormaltasuna eta heriotza eragiten dituen BP-3aren kontzentrazio-muga. Ehunetan detektatutako konposatu nagusia oxibentzona izan zen, eta, BP8arekin (bentzofenona-8, BP-3ren metabolitoa) batera, \% 65 baino maiztasun altuagoan neurtu zen. Bi konposatu horien kontzentrazioak 1-38,4 ng/g ww eta 1,3-19,9 ng/g ww izan ziren, hurrenez hurren.BP-3aren I. faseko hidroxilazio eta desmetilazioaren ondorioz BP-8 metabolitoa eratzen dela adierazten dute jasotako antzeko balio horiek [20].

Konposatu organikoak koraletako ehun bigunetan soilik detektatu ziren, horien mailak kaltzio karbonatozko egituretan detekzio-limitea- 
ren (MDL) balioen azpitik baitzeuden; horren arrazoia da konposatuen lipofilizitatea $\left(\log \mathrm{K}_{\mathrm{ow}}>3\right)$ altuagoa dela. Horrela, biometatzeko gaitasuna dute, eta haien eragina maila trofiko baxuetako (muskuiluak) eta altuetako (arrainak eta izurdeak) itsas organismoetan ikusi izan da. Biometaketaren arrazoiak hobeto ulertzeko asmoz, BAF balioak kalkulatu ziren, koralen ehunetako iragazki-kontzentrazioa, inguruneko uretako kontzentrazioekin zatituz. Oro har, iragazkien biometaketa potentziala haien $\mathrm{K}_{\text {ow }}$ balioekin erlazionaturik dago. Lortutako oxibentzonaren $\log _{10}$ B AF balioak $(2,21-3,01)$ aurretik Danio rerio zebra-arrainekin egindako ikerketan lortutako balioak $(1,28-1,97)$ baino altuagoak izan ziren. Hala ere, ezberdintasun horiek espezie bakoitzaren xurgatze-, pilatze- eta metabolizatze-gaitasun ezberdinengatik ager daitezkeela kontuan hartu behar da [20].

Urte berean, Peng $X$ eta kideak, metaketak biotan duen eragina eta ondoriozko ekosistema osoaren kaltea aztertzeko asmoz, 13 iragazki ultramoreren biometaketa- eta biomagnifikazio-ezaugarriak aztertu zituzten [23].

Sedimentuetatik konposatu kimikoen metaketa itsas biotan aztertzeko asmoz, biota-jalkin metaketa-faktorea (BSAF) kalkulatu zuten. Lortutako balioak 0,003 eta 2,152 bitartekoak izan ziren; batez besteko baliorik altuena $(1,105)$ UV531 konposatuarena izan zen. Oxibentzonaren baliorik altuenak $(43,4)$ Menippe mercenaria karramarroan detektatu ziren. Oro har, iragazki ultramoreak arrainetan ornogabeetan baino gehiago pilatu ziren. Organismoen elikatze-ohiturei erreparatuz, detritu eran (masa solidoa partikulatan deskonposatzea) elikatzen diren espezieek metaketa-maila altuagoak erakutsi zituzten [23].

Elikadura-katean konposatu kimikoen biomagnifikazio-potentziala deskribatzeko magnifikazio-faktore trofikoak (TMF) eta biomagnifikaziofaktoreak (BMF) erabili zituzten. TMF balioak 0,35 eta 1,70 bitartekoak izan ziren, baina gehienek 1 baino balio baxuagoak izan zituzten; seguruenik, biomagnifikatzen ez diren seinale. Hala ere, elikadura-kateko maila trofikoaren tartea $(2,46-4,21)$ ikerketa honetan mugatua izan zela kontuan hartuz, TMF balioek ez dute biomagnifikazioa argitzeko balio askorik. Hala, Harpadon nehereus arrainetan eta antxoetan lortutako kontzentrazioak erabiliz, BMF balioak kalkulatu ziren, eta oxibentzonaren balioa $(0,42)$ baxuenetarikoa izan zen [23].

Uretan identifikatu eta pilatutako BP-3aren kantitateak ez du soilik koraletan eragiten, baita uretako beste espezie batzuetan ere: alga berdearen garapen eta fotosintesiari eragiten dio, muskuilu gazteetan akatsak sortzen ditu, eta itsas trikuen immunitate-sisteman eta ugalketan kalteak. Gainera, izurdeen ehunetan metatu, eta hurrengo belaunaldiei igarotzen zaie. Arrain arrek emeen ezaugarriak garatzea eta emankortasun- eta ugalketa-murrizketa eragiten diete [24]. 
Braush eta Rand, Daphnia magna (ornogabea) eta, Oncorhynchus mykiss eta Oryzias latipes (arrainak) aztertu zituen, eta haien LC50ak kalkulatu zituzten (1,9ppm, 749ppb eta 620ppb, besteak beste). Hala, iragazki ultramoreek arrainetan uretan baino pilaketa biologikoaren faktore hobea dutela ondorioztatu zuten [25].

Biometaketa- eta biomagnifikazio-parametroak balioestearen garrantzia azpimarratu beharra dago; ekosistemaren osasuna kaltetzeaz gain, iragazkien pilaketak gizakietan ere eragina duelako, itsas elikagaien kontsumoa dela eta.

\section{TENPERATURA ETA OXIBENTZONAREN ERAGIN SINERGIKOA}

Gaur egun, aldaketa klimatikoarekin erlazionaturiko faktorerik adierazgarriena tenperatura-igoera da. Horrek eragile toxikoen banaketak eta organismoek horiei ematen dieten erantzuna alda ditzake. Muñiz-Gonzalez eta kideek egindako ikerketan, tenperaturaren eta estres kimikoaren eraginak BP-3aren eraginpean aztertu zituzten, Chironomus riparius larbak erabiliz. Horretarako, tenperatura ezberdinetan $\left(18,5\right.$ eta $\left.23{ }^{\circ} \mathrm{C}\right)$, detoxifikazio-mekanismoekin, sistema endokrinoarekin eta estres-erantzunekin erlazionaturiko gene-mailak ikertu ziren. Hala, garapenean, homeostasia mantentzeko zelularen gaitasunean eta agente toxikoen desaktibazioaren kudeaketan tenperatura eta oxibentzonaren artean ematen den eragin sinergikoak sortutako eraginak aztertu ziren [26].

Detoxifikazioa, immunitate-sistema eta nerbio-sistemarekin erlazionatutako entzimen aktibitatea BP-3aren bioeraldaketa-mekanismoaren, infekzioen garapenerako erraztasunaren eta jarrera-aldaketen indikatzaile gisa aztertu ziren. Hala, organismoaren kaltea azpiorganismo-mailan aztertzeko asmoz, GST (Glutation-S-transferasa), PO (feniloxidasa) eta AChE (azetilkolinesterasa) entzimen jarduerak aztertu ziren [26].

Oxibentzonaren eta tenperaturaren eragina detoxifikazioko I fasean aztertzeko, P450 zitokromoaren bi generen (cyp4d2 eta cyp6b7) ARN mezularien $(\mathrm{ARNm})$ mailak neurtu ziren. Zitokromo-familia berean tenperaturaren arabera (18,5 edo $23^{\circ} \mathrm{C}$ ) erantzun ezberdinak izan daitezkeela aztertu zuten. Bestalde, aztertutako bi GST geneen jardueraren murrizketak, 24 orduko BP-3 10 eta $100 \mu \mathrm{g} / \mathrm{L}$ kontzentrazioan, detoxifikazio-mekanismoen gutxitzea ekarri zuen, hau da, glutationarekin (GSH) konposatua konjugatuz zelulak toxikoa kudeatzeko duen gaitasunaren murrizketa. Beraz, detoxifikazio-mekanismoen asaldurek I, II eta III faseetako geneen espresioaren aldaketa adierazi zuten [26].

Era berean, infekzio mikrobianoen aurrean, POaren jardueraren bidez, ur-jauzi proteolitikoak jartzen dira martxan, melanizaziora eta koagulaziora bideratuz. Lehen prozesuak, POaren beharra dauka, melanina sortzeko zauri eta inguruetan. Entzima horren aktibitatearen igoerak $100 \mu \mathrm{g} / \mathrm{L}$-tan 
$18,5^{\circ} \mathrm{C}$-an aztertu ziren, baita $10 \mu \mathrm{g} / \mathrm{L}$-an $23{ }^{\circ} \mathrm{C}$-an ere. Beraz, BP-3ak eta tenperaturak entzima horren aktibitatea areagotu dezakete; hartutako immunitatearen parte denez, honen erantzuna eraldatzen da. Horrez gain, AChE entzimaren jardueraren areagotzea $10 \mu \mathrm{g} / \mathrm{L}$-an $23{ }^{\circ} \mathrm{C}$-tan nabarmendu zen; hori larbaren biziraupenerako arriskua zen [26].

Lortutako datuak aztertuz, oxibentzonaren eraginaren intentsitatea aldaketa klimatikoarekin erlazionatuta dagoela ondoriozta daiteke. Zenbat eta tenperatura altuagoa izan, orduan eta esanguratsuagoak dira emaitzak. BP-3aren eragina $C$. riparius-en larban azaltzearen garrantziak biomagnifikazioaren garrantzia azpimarratzen du. Bizi-zikloaren arabera (4. irudia), larba ingurune urtsuetatik azaleratu eta euli bilakatzen da. Euliak mundu mailako banaketa du eta, ondorioz, itsasoan jatorria ez duen beste animalia-espezie batek jan dezake. Uretan bizi denean, arrainek jan dezakete; horrek arazoa magnifikatzen du [27].
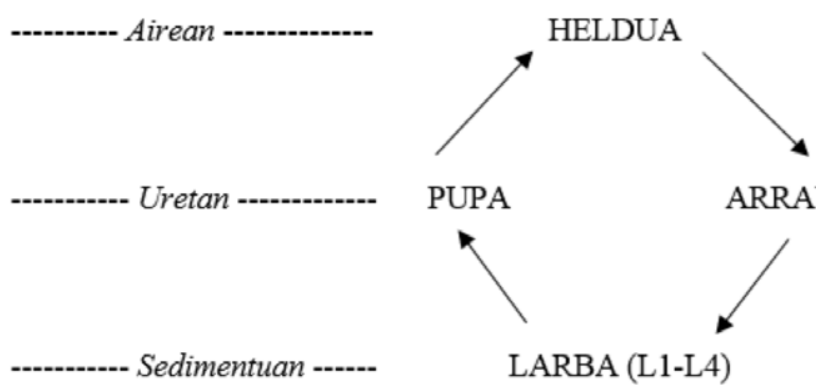

ARRAUTZA

LARBA (L1-L4)

4. irudia. Chironomus riparius-en bizi-zikloaren faseen irudikapena [27].

\section{OXIBENTZONA SAIHESTEKO ALTERNATIBAK}

Behin oxibentzonak koraletan duen eragin toxikoa aztertuta, itsas ekosistemarentzat eta gizakiarentzat seguruagoak izan daitezkeen konposatuen bilaketa beharrezkoa dela azpimarratu daiteke.

Iragazkien eraginkortasuna baloratzeko asmoz, hainbat irizpide kontuan hartu behar dira. Uhin-luzeraren arabera, UV irradiazioa hiru bandatan sailkatzen da: UVA (320-400 nm), UVB (290-320 nm) eta UVC (200-290 nm). Hala, iragazkiek zer uhin-luzeratan jarduten duten, halako espektroa izango dute. Ekintza-mekanismoari dagokionez, iragazki organiko (kimiko) eta inorganikoak (mineralak) bereiziko dira (5. irudia). Eguzkitako kremek eritema prebenitzeko duten gaitasuna SPF (Eguzkiaren 
babeserako faktorea edo, ingelesez «Sun Protection Factor») faktorearen bitartez adierazten da; horretarako, UVBaren aurkako babesa neurtzen da. Iragazki eraginkorrenak espektro zabalekoak dira, uhin-luzeraren tarteak banda ezberdinetan adierazten dituztenak [30].

Iragazki organikoei (BP-3) dagokienez, A eta B motako UV izpiak xurgatu ditzaketen arren, gehienek B motakoak soilik xurgatzen dituzte. Haien ekintza xurgagarria itzulgarria denez, molekula berak egin dezake behin eta berriz bere ekintza [28]. Normalean, iragazki organikoek (oxibentzona salbu [29]) mineralek baino fotoegonkortasun txikiagoa dute; ondorioz, fotolisia eta oxigenoaren erradikal askeak sortzen dira, eta toxikotasuna eragiten dute. Gehien erabiltzen diren iragazki mineralak zink oxidoa eta titanio dioxidoa dira; nanopartikula eran administratzen dira azalaren zuritze-efektua saihesteko asmoz. Izpiak azaletik xurgatu, sakabanatu eta islatu ditzakete; beraz, haien ekintzaren ondorioz, UV estaldura zabalagoa eta SPF altuagoa izatea ahalbidetzen die [28].

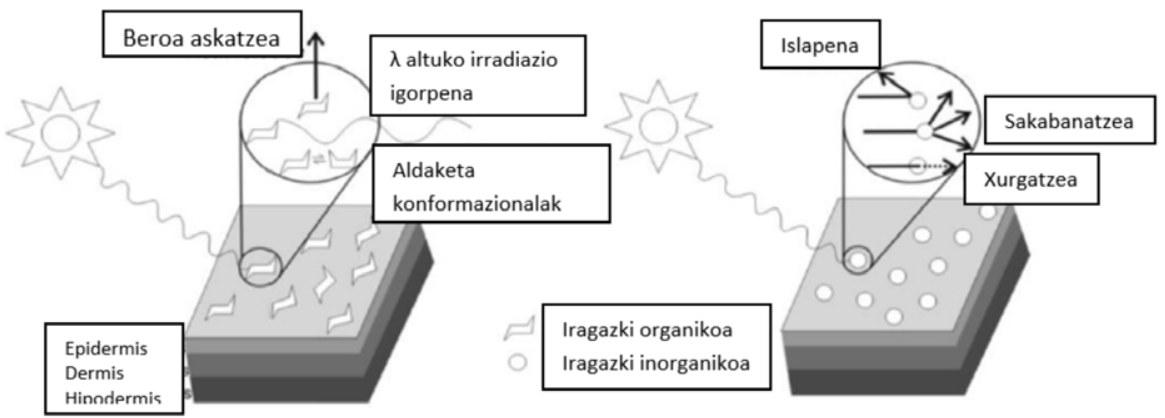

5. irudia. Iragazki ultramore organikoen (ezkerra) eta inorganikoen (eskuina) ekintza [30].

Espektro zabaleko (UVA) testa ea produktu baten uhin-luzera kritikoa gutxienez $370 \mathrm{~nm}$-koa den neurtzen duen metodo analitikoa (in vitro) da. Gutxieneko horrek ultramore aldeko kurbaren azpiko azalera totalaren \% 90 adierazten du. Beraz, uhin-luzera kritikoa oinarri hartuta, UVA izpien babeserako eraginkorrenak abobentzona, titanio dioxidoa eta/edo zink oxidoa dira. Guztietatik, zink oxidoak ditu ahultze-ultramore $(290-400 \mathrm{~nm})$ eta muturreko xurgatze $(290-385 \mathrm{~nm})$ onenak: UVB espektroaren \% 100 eta UVAren \% 95 estaltzen du [31].

\subsection{Eguzkitako kremen FDAren erregulazioa}

Azken 40 urteetan, FDAk (Food and Drug Administration) eguzkitako kremen konposatuen erregulazioa egin du; osagaien segurtasunaren ara- 
bera, hiru kategoriatan sailkatu ditu. I. kategorian, produktu seguru, eraginkor eta ondo etiketatuak batzen dira; adibidez, titanio dioxidoa $\left(\mathbf{T i}_{\mathbf{2}} \mathbf{O}\right)$ eta zink oxidoa ( $\mathrm{ZnO})$, \% 25etik gorako kontzentrazioan era seguru eta eraginkorrean erabili daitezkeelako ${ }^{32}$. II. kategoriak kontrako ezaugarriak dituzten osagaiak batzen ditu, hau da, seguru eta eraginkorrak ez diren osagaiak. Bukatzeko, III. kategoriari dagokionez, kategoria horretako konposatuen datu osagarriak beharrezkoak direnez, haien erabilera segurua ez dela ondorioztatzen da, eta arriskutsutzat har daiteke; adibidez, oxibentzona konposatua.

Gehien erabiltzen diren konposatuak nanopartikula-mailako $(<100 \mathrm{~nm})$ $\mathrm{ZnO}$ eta $\mathrm{Ti}_{2} \mathrm{O}$ dira; toxikotasun esanguratsuagoa dute itsas ekosistemarentzat eta gizakiarentzat mikrotamainakoek baino. UVA blokeatzeko eraginkortasun txikiagoa dute, eta erradikal askeak askatzeko gaitasuna. EPAk argitaratutako berrikuspen bibliografikoan, nano- $\mathrm{Ti}_{2} \mathrm{O}$-ak arrainetan erakutsi du eragin nabarmenena, eta $\mathrm{ZnO}$, arrainetan ezik, arrezifezko uharrietan ere agertzen dira. Kontzentrazio altuetan, koralen zuritzea eragiteko gai da, zink ioi toxikoagotan eta oxigeno erradikaletan banatzeko ahalmena duelako [33]. Beraz, mikroneurriko $\mathrm{ZnO}$-ak eta $\mathrm{Ti}_{2} \mathrm{O}$-ak $(0,1-10 \mu \mathrm{m}$ edo 100 $10.000 \mathrm{~nm}$ zabaleran) azalean hobeto mantentzeko eta itsas ingurunean ez sartzeko gaitasun handiagoa dute. Gainera, partikula horiek ez dira azala edo hesi hematoentzefalikoa zeharkatzeko gai [17].

2019ko otsailean, FDAk proposatutako eguzkitako kremen erregulazioaldaketak, bi konposatu seguru eta eraginkor horiek aipatzeaz gain, azido aminobentzoikoa (PABA) eta trolamina salizilatoa deskribatzen ditu ez hain seguru eta eraginkortzat. Gainerako 12 konposatuei buruz (BP-3a barne), segurtasunaren inguruko informazio gehiago beharrezkoa da. Dosifikaziomoduari dagokionez, aerosola, olioa, lozioa, krema, gela, koipea, orea, pomada eta barrak, seguru eta eraginkortzat deskribatzen ditu. Hala ere, aerosolen administrazioaren ondorioz hondarrean gera daitekeen krema itsasoratzea erraza denez, erabilera segurua zalantzan jartzen hasi da [34].

Horrez gain, FDAk SPF maximoa 50+-etik 60+-era igotzea proposatzen du. Faktorea 15 edo altuagoa dutenak espektro zabalekoak izatea eta SPFa igotzen den heinean babeserako espektro zabala areagotzea eskatzen du. Etiketaren aurrealdean osagai aktiboen zerrenda alfabetikoki gehitzea proposatzen du. Horrez gain, SPFa 15etik beherakoa dutenek «Azaleko minbizia/azalaren zahartzea alerta begiratzea» aurrealdean izan behar dute. Tipografia- eta kokapen-aldaketak beharrezkoak dira urarekiko erresistentzia, espektro zabala eta SPFa nabarmentzeko. Bukatzeko, FDAk ez ditu seguru eta eraginkortzat hartzen [34] eguzkitako kremen eta intsektuak uxatzeko produktuen konbinaketak.

Nahiz eta FDAk konposatu horiek onartu, nanopartikula-tamaina izatearen ondorioz, segurtasunaren inguruko hainbat arazo aztertu dira ${ }^{34}$. Ho- 
rregatik, Bernstein eta taldeak silikato, polialkilsilseskioxano, eta polidimetilsiloxano frakzioz osaturiko geruzarekin estali zituen $\mathrm{ZnO}-\mathrm{a}$ eta $\mathrm{Ti}_{2} \mathrm{O}-\mathrm{a}$ eta gisako konposatuak, eta horien segurtasuna aztertu. Konposatu horiek fotoegonkortasuna handitzen dute, eta energia-iturriekiko interakzioan jardutean sortutako erreaktibitatea murrizten. Gainera, antioxidatzaileekin formulatuz gero, erradikal askeen hedapena ere murrizten da. Topikoki erabiltzen diren agente antioxidatzaile horien artean, $\mathrm{C}$ bitamina, kerzetina, Aloe vera, silimarina, kromanoa, te berdearen erauzkina, ginsenga eta Polypodium leucotomos erauzkina segurutzat hartu dira [35].

Formulazio horiek SPF/PA (photoaging edo fotozaharkitzea) balio maximoak eskaintzen dituzte, eta uraren eraginpean 40-80 minutu bitarteko babesa. Hala, iragazki mineraletan oinarrituriko konposatu geruzatuak gizakiaren osasuna babesteko baliogarriak izateaz gain, ingurumenarentzat (koralezko uharriak barne) ekologikoak direla ondorioztatu zen [35].

\subsection{Antioxidatzaile naturalak}

UV irradiazioek (UVR) bi mekanismo ezagunez sortzen dute azalean kaltea: zuzenean, biomolekulen energia-absortzioaren bidez edo, zeharka, oxigenoaren espezie erreaktiboen (ROS) eta nitrogenoaren espezie erreaktiboen (RNS) ekoizpena areagotuz. Konposatu antioxidatzaileek azalari gaitasuna ematen diote babesteko duen barne-gaitasuna hobetzeko eta ROS molekulak neutralizatzeko. Landareek ezaugarri antimutageniko eta antikartzinogenikoak dituzte, hanturaren kontrako eraginaren, erantzun immunearen eta detoxifikazioaren estimulazioa sustatzen dutelako. Gainera, antioxidatzaileen modulazioaren eta gene espresioaren aldaketan ere parte hartzen dute [36]. Horregatik, konposatu natural horiek, haien erabilerak osagai kimikoen murrizketa ekar dezakeenez, alternatiba gisa erabil daitezke.

Melatonina zianobakterio, alga eta hainbat landaretan (intxaurrondo, baba, onddo eta Scutellaria biacalensis) aurkitzen den konposatua da. Hantura bitartekarien modulazioaren bidez, eragin fotobabesgarria erakutsi du. ROS molekulak potentzia handiz harrapatu, eta zelularen kalte eta hantura prebenitzeko gaitasun antioxidatzailea lortzen du. Horrez gain, melatoninaren metabolitoa den 4-hidroximelatoninak eragin antioxidatzaile indartsuagoa daukala ikusi da. Ikerketek frogatu dute UVBekiko esposizioaren ondoren ROS-ekoizpenaren murrizketa eragiten duela. Honekin batera, p53 espresioaren areagotzea, DNAren konponketa eta CPD (ziklobutano pirimidin dimeroak, eragin kartzinogenikoaren ondoriozko mutazioak) eraketaren murrizketa eragiten ditu. Nahiz eta mekanismoa ez den guztiz ezaguna, gehiegizko ROS-presentzian Nrf2-a (ingelesez, nuclear factor erythroid-derived 2-like 2) aktibatzearen ondorioz ager daitekeela uste da [36]. 
Tea, mahatsaren erauzkinak edo gisako landare-jatorria duten polifenolek UVBaren eraginezko kartzinogenesi eta hanturaren kontrako babesa erakutsi dute. Tearen polifenolen mekanismo fotobabeslea UVBek eragindako immunoezabapen lokal eta sistemikoa saihestearen bidez sortzen da. Gainera, polifenolek hidrogeno peroxido $\left(\mathrm{H}_{2} \mathrm{O}_{2}\right)$ eta oxido nitriko dermiko eta epidermikoen ekoizpena murrizten dute. Bestalde, mahatsaren erauzkinaren bidez, erresberatrola (konposatu polifenolikoa) lortzen da. Konposatu horrek COX-2-a (ziklooxigenasa-2) inhibituz, ornitina deskarboxilasa inhibituz, eta $\mathrm{H}_{2} \mathrm{O}_{2}$-aren eta lipidoen peroxidazioa murriztuz lortzen ditu eragin babesleak. Hala, ezaugarri antioxidatzaileak, minbiziaren kontrakoak eta hanturaren aurkakoak dituen agentetzat jotzen da. Ikerketek erresberatrolak UVAek eragindako estres oxidatiboa ahultzen duela ondorioztatu dute, Keap1 proteinaren atzera-erregulazioa dela medio [36].

Kerzetina (flabonoidea) landareen pigmentuetan aurkitzen den konposatu polifenolikoa da. Ezaugarri antioxidatzaileak, hanturaren kontrakoak eta antikartzinogenikoak ditu. Egituran dituen hidroxilo taldeei esker eragin antioxidatzaile indartsua dauka [36].

Honokiola Magnolia generoko hainbat landaretatik isolatzen den konposatu bifenoliko hidroxilatua da. Hainbat ezaugarri farmakologiko ditu: antioxidatzaile, hanturaren aurkakoa, antiangiogenikoa, antikartzinogenikoa eta antibakterianoa. Horrez gain, melanometan eragin antineoplasikoak dituela erakutsi du. Eragin fotobabesleari dagokionez, izpi UVek eragindako inmunoezabapena deuseztatzeko gaitasuna du: COX2-a inhibitzen du, eta, ondorioz, PGE2-a ekoizten da [36].

Apozininari dagokionez, Picrorhiza kurroa landarearen sustraietatik erauzitako konposatua da. NADPH oxidasaren (NOX) aktibitatearen inhibitzailea da; ondorioz, ROS-ekoizpena ere blokeatzen du. NOX2 inhibitzaile horren aktibitatea NADPH oxidasa konplexuaren eraketa blokeatzean agertzen da [36].

Aloe vera hostoen erauzkinek hainbat konposatu aktibo dituzte: proteinak, mineralak, karbohidratoak eta bitaminak. Egindako ikerketetan ikusi da UVAek eragindako erredox desoreka eta lipidozko mintzaren oxidazioa murrizten dituela. Horrez gain, zelulen biziraupen orokorra areagotzeko gaitasuna erakutsi du. Topikoki erabiltzeko, Aloe vera eta kurkumina enkapsulatzean eragin antioxidatzaileak hobetzen dira. Kurkuminak (turmerikoa) ARNm mailan UVBek induzitutako TNF- $\alpha$ inhibitzeaz gain, MMP-1en (matrize-metaloproteinasa-1) espresioa keratinozito eta fibroblastoetan murrizten du [36]. Liu eta taldeak egindako ikerketan, fibroblastoetan UVAek eragindako fotozaharkitzearen babeserako gaitasuna duela ondorioztatu zen [37].

Astalikardu edo Silybum marianum landaretik erauzten diren konposatu ohikoenak (osagai aktibotzat jotzen direnak) silibinin A eta B dira. 
Konposatu horiek DNA konpontzeko duten gaitasuna dela-eta, larruazaleko minbiziaren prebentziorako agente eraginkorrak izan daitezkeela uste $\mathrm{da}^{36}$. Hala, UVBek eragindako larruazaleko kartzinogenesiaren prebentzioan duen eraginkortasuna frogatu da. Silibininak, topikoki aplikatuta, saguen biziraupena 3-4 aste luzatzen duela erakutsi du. Artikuluan, silibininaren ekintzan p53-ak lesioen ezabapenean daukan garrantzia azpimarratu da. Hala ere, silibininaren ekintza NER bidean (nukleotidoen bereizketaren konpontze bidea; UVBek eragindako DNA-kaltearen konponketarako bide nagusia) p53arekiko independentea dela ondorioztatu da [38].

\subsection{Mikosporina motako aminoazidoak}

Egungo hainbat kezka direla eta, oinarri naturaleko konposatuak aztertzen hasi dira. Itsas organismoek mikosporina motako aminoazidoak (MAA) erabiltzen dituzte babes kimiko gisa. Ziklohexenimina-nukleoarekin edo ziklohexenona-eraztunarekin osatuta daude eta hainbat talde funtzional dituzte. Ikertzaileek konposatu horien (sinorina, gadusol, palitina) lotura konjokatu bikoitzek eguzkiarekiko babesa ematen dutela uste dute, energia altuko UVRak xurgatzeko eta bero gisa askatzeko gaitasuna baitute. Ezaugarriei erreparatuz, pisu molekular baxua dute, uretan disolbagarriak dira, eta argiaren edo beroaren eraginpean egonkorrak. Horregatik, eguzkitako kremen konposizioan osagai gisa erabiltzeko aztertzea interesgarria izan daiteke [39].

Porphyra umbilicalis alga gorritik erauzitako sinorinaz osaturiko kremak Europako bi enpresek saltzen dituzte jada. Hala ere, alga-espezie horiek denbora luzea behar dute batuak izan aurretik, eta, beraz, ikertzaileek, alternatiba gisa, sinorina ekoizten duen zianobakterioa diseinatu dute. Fischerella zianobakterioaren genoma aztertu zuten, eta gene horiek $S y$ nechocystis zianobakterioan gainadierazi zituzten, bi astetan nahikoa den sinorina kantitatea ekoizteko gai dena. UVB izpien eraginpean, sinorinadun zianobakterioaren zelulek hazkuntza hobea izan zuten; horrek konposatuak babesa ematen duela adierazten du [39].

Bestalde, ikertzaile batzuek aurkitu dute ornodun batzuek, hala nola zebra-arrainak, gadusol izeneko konposatua ekoizten dutela, aurretik azaldutako osagaiak bezala UVB izpietatik babesten duena. Diseinatutako legamian gadusolarekin erlazionatutako geneak txertatuz, zelulen UVB argiarekiko sentikortasuna murriztu zuten. Ordenagailu bidez eginiko eredua erabiliz, UV babeserako MAAren konposatu guztiz beharrezkoen eskema osatu zuten. Aminoziklohexenimina nukleoaren ezaugarriek gadusola eguzkitako kremen konposatu egokia egiten dute; UV-xurgapen indartsuaren eta argiaren eraginpean egonkor mantentzearen ondorioz [39].

Palitina deituriko MAA Chondrus yendoi alga gorritik erauzitako konposatua da, urte osoan zehar batu daitekeena. Gainera, laborategian hazi- 
tako giza larruazaleko zeluletan UVAek eta UVBek eragindako kalteetatik babesten dute [39]. Alga-espezie askok MAA konposatuak ekoizten dituztenez, haien eragin fotobabeslea UVak xurgatzeko propietateen ondorio da. Corallina pilulifera alga gorriaren metanol erauzketak ekintza antioxidatzaile indartsua agertu du UVAek eragindako estres oxidatiboaren kontrako babesean. Gainera, MMP-2 eta -9 espresioaren murrizketa eragiten duela ikusi da. Ecklonia cava alga marroiari dagokionez, polifenoletan aberatsa denez, estres fotooxidatiboaren kontrako eragin babesgarria dauka [36].

\subsection{Konposatu glukosinolatoak eta deribatuak}

Itsasoko organismoez gain, zelaietako belarraren loreak ezaugarri aproposak erakutsi ditu eguzkitako kremen konposatu bezala erabiltzeko. Landarearen olioa xanpua eta produktu edergarriak egiteko erabiltzen da. Olioa erauzteko prozesuak haziz osatutako «irina» uzten du, landare-hondakin ugariz osaturik dagoena. Irin hori glukolimnantina konposatu glukosinolatoaren iturri garrantzitsua da [39].

Aldez aurretik aztertutako glukosinolato deribatuen (sulforafanoa, adibidez) ezaugarri fotobabesgarriak kontuan izanik, ikertzaileak glukolimnantinaren deribatuek propietate bera duten aztertzen hasi dira. Sulforafanoa brokolian aurkitzen den antioxidatzaile naturala da; ezaugarri antikartzinogeniko, antidiabetiko eta antimikrobianoak ditu. Landarearen erauzkinak topikoki aplikatutako saguetan UVRek eragindako hanturaren eta edemaren kontrako babesa agertu du. Erauzkinak ematen duen babes hori, Nrf2 aktibazioaren eta ondoriozko fase 2ko entzima antioxidatzaileen erregulazioaren ondorio dela ondorioztatu da [39].

Carpenter eta taldeak eginiko ikerlanean, Limnanthes alba zelaietako belarraren 3-metoxibentzil isotiozianato (MBITC) eta 3-metoxifenil azetonitrilo (MPACN) deribatu glukosinolatoak aztertu ziren. Lehen aldiz, deribatu horien ezaugarri fotobabeslea azaldu zen; UVBek eragindako DNA- kaltea, proliferazioa eta MMParen espresioa murrizten dituztela ondorioztatu zen. Gainera, MBITCak (baita sulforafanoak ere) eragindako MMP-1 espresioaren inhibizioak azalaren zaharkitzearen prebentzioan jardun dezakeela ondorioztatu da. Larruazaleko minbiziaren inbasio eta metastasien prebentzioa MPACNak MMP-3aren espresioa inhibitzeko duen gaitasunari egotzi zaio. Hala, konposatu horiek fotozaharkitzearen eta fotokartzinogenesiaren prebentziorako erabilgarriak izan daitezkeela ondorioztatu da [40].

Bi konposatu horiek (MBITC eta MPACN) ekintza-mekanismo ezberdinak dituzte. MBITCak keratinozito primarioen proliferazioa inhibitzen du, ondoriozko zitotoxizitatea emanez. Kontuan hartu behar da eragina dosiaren mendekoa dela: zenbat eta kontzentrazio altuagoa izan, orduan eta eragin toxiko handiagoak izaten ditu. Zelulen galera orekatzeko, proliferazio- eta ezberdintze-prozesuak areagotzen dira; areagotze hori ETaren (epitelioaren 
lodiera) eta PCNA+ (proliferazioan dauden zelulen antigeno nuklearra) zelula epidermikoen gehiagotzean islatuta dago. Horregatik, MPACNaren eta MBITCaren kontzentrazio-tarte egokia aukeratzea garrantzitsua da. Hala, eragin onuragarri maximoak eta eragin ez-desiragarrien ezabatzea lortzen dira. Nitrilo deribatuak, ordea, ez du eragin zitotoxikorik erakutsi [40].

\section{OHITURA-ALDAKETAK ETA BIZTANLERIAREN HEZIKETA}

Urteetan zehar, larruazaleko minbizien tasa handitzearen kausa nagusia gizakiaren jokabidea dela uste izan da. Ekintza gehiago kalean egiteak eta eguzkia hartzeko ohitura berriek gehiegizko esposizioa ekar dezakete. Askok kolore beltzarana edertasun- eta osasun-sinbolotzat hartzen dute, izan ditzakeen ondorio larriak aintzat hartu gabe.

Eguzkitako kremen erabilera neurriz erabiltzeko eta aldi berean larruazala osasuntsu mantentzeko asmoz, FDAk biztanleriak jarraitzeko zenbait aukera proposatu ditu. Alde batetik, eguzkiak gogorren jotzen duen ordue$\tan$ (eguerdi aldera) gerizpean jartzea gomendatzen da; aterkiaren azpian, adibidez. Halaber, eguzkirako kapelak eta larruazala babesteko arropa luzeak janzteak eguzkitako kremak erabili beharra murrizten du, ageri diren gorputz-ataletan baino eman behar ez delarik krema. Eguzkitako betaurrekoek eguzki-izpietatik babesten gaituzte, begietan arazoak sortzea saihestuz. Hala, eguzkitako kremen erabilera murriztu daiteke, eta konposatuak itsasora sartzea ekidin [34].

Aurretik azaldutako ohitura-aldaketez gain, zenbait erakundek argitaratutako gidaliburu praktikoan, eguzkiaren mundu-mailako UV indizea (IUV) definitzen da; haren bidez, lur-azalean UV irradiazioak duen intentsitatea neurtzen da. Indize horren balioa zenbat eta handiagoa izan, hainbat eta aukera gehiago daude larruazaleko eta begietako lesioak pairatzeko, eta lesioak azkarrago ager daitezke. Horregatik, biztanleria indizearen inguruan heztea babes egokirako garrantzitsua da, UV izpien eragipean egoteak dakartzan arriskuen kontzientzia handitzeko. Horretarako, IUVen aurkezpen grafiko edo piktogramen bidez, IUV kontzeptua ulertzen lagundu dezakete [41].

Osasunarentzat eragin ez-desiragarriak izateko arriskua UVarekiko esposizio jarraituen ondoriozkoa izan daitekeela azpimarratu behar da. Horregatik, egunean eguneko eguzki-esposizioa aisialdian jasotakoa bezain garrantzitsua da. Hala, biztanleriak eguzkitan emandako denbora murriztuz gero, osasunarriskuak eta horrek dakarren eguzkitako kremen erabilera murriztu daitezke.

Gidaliburu honetan, UV irradiazioaren eta horren eraginen inguruko ohiko sineste faltsuak azaltzen dira (1.taula). Mito hauen adibidetzat, kolore beltzarana osasuntsua dela gizakiarentzat: irradiazioek sortutako kalteen kontrako organismoaren defentsarako mekanismoa da, eta ez da gi- 
zakiarentzat osasuntsua. Beste ohiko mitoen adibide, egun hodeitsuetan larruazala ezin daitekeela erre: egun hodeitsuetan, UV irradiazioen \% 80k dentsitate baxuko hodeiak zeharkatu ditzake; beraz, horietan ere erretzeko arriskua badago, nahiz eta berotasuna ez sentitu. Adibide horiek bezalako mitoei aurre eginez, eguzki-izpien babeserako ohiturak alda daitezke [41].

Horrez gain, umeentzat gomendio bereziak aipatzen dituzte, arrisku handiko taldea osatzen baitute. Haurtzaroko esposizio luzeak gerora lurrazaleko minbizia izateko arriskua handitu dezake, eta begietan kalteak sor ditzake, umeek azal eta begi sentiberak dituztelako. Beraz, haur eta gazteak eguzkitik babestea ezinbestekoa da ${ }^{41}$.

1. taula. UV irradiazioaren arriskuak: mitoak eta errealitateak [41].

\begin{tabular}{l|l}
\hline \multicolumn{1}{c|}{ MITOAK } & \multicolumn{1}{c}{ ERREALITATEAK } \\
\hline $\begin{array}{l}\text { Kolore beltzarana osasunga- } \\
\text { rria da. }\end{array}$ & $\begin{array}{l}\text { Kolore beltzarana UV irradiazioak eragindako kalteen } \\
\text { aurka organismoak daukan defentsarako mekanismoa da. }\end{array}$ \\
\hline $\begin{array}{l}\text { Kolore beltzaranak eguzkitik } \\
\text { babesten gaitu. }\end{array}$ & $\begin{array}{l}\text { Azal argia duten pertsonetan, kolore beltzaranak babes } \\
\text { eskasa ematen du: SPF 4k adinakoa. }\end{array}$ \\
\hline $\begin{array}{l}\text { Egun hodeitsuetan ez gara } \\
\text { erretzen. }\end{array}$ & $\begin{array}{l}\text { UV irradiazioen \%80k hodei ez oso dentsoak zeharkatu } \\
\text { ditzake. Are gehiago, atmosferako lanbroak UV irradia- } \\
\text { zioen esposizioa areagotu dezake. }\end{array}$ \\
\hline $\begin{array}{l}\text { Uretan ez gara erretzen. } \\
\text { dira arriskutsuak. }\end{array}$ & $\begin{array}{l}\text { Urak UV irradiazioen kontrako babes minimoa eskaintzen } \\
\text { du. Gainera, uraren islak esposizioa areagotu dezake. }\end{array}$ \\
\hline $\begin{array}{l}\text { Noguan, UV irradiazioak ez } \\
\text { rotasuna ez badu sentitzen, } \\
\text { ez gara erretzen. }\end{array}$ & $\begin{array}{l}\text { Orokorrean, neguko hilabeteetan UV irradiazioak murriz- } \\
\text { ten dira. Hala ere, elurraren islapenak guztizko esposizioa } \\
\text { bikoiztu dezake, altitude altuetan bereziki. Udaberri ha- } \\
\text { sieran, tenperaturak baxuak baina eguzki-izpiak pentsatu } \\
\text { baino indartsuagoak baitira, zuhurrago ibiltzea gomenda- } \\
\text { tzen da. }\end{array}$ \\
\hline $\begin{array}{l}\text { Krema babesleek eguzkitan } \\
\text { luzeagoz egotea ahalbide- } \\
\text { tzen dute. }\end{array}$ & $\begin{array}{l}\text { Eguzkiaren babeserako kremak ez dira eguzkitan egoteko } \\
\text { esposizio-denbora luzatzeko erabili behar, baizik eta ezin- } \\
\text { besteko esposizioa dagoenean babesa areagotzeko. Neu- } \\
\text { tugi handi batean, kremek eskaintzen duten babesa azalean } \\
\text { ondo aplikatzearen mende dago. }\end{array}$ \\
\hline UV irradiazioen ondoriozkoa.
\end{tabular}




\section{ONDORIOAK}

Koralezko arrezifeak biodibertsitate ugaria batzen duten ekosistema dibertsoenetarikoak dira, eta egungo hainbat faktorek mehatxatzen dituzte. Arrisku horien artean, klima-aldaketak eragindako tenperaturaren igotzea azpimarratzen da. Tenperatura-igoera horrek, gizakiak eguzkitako kremak erabiltzea nabarmenki areagotzeaz gain, krema horiek koraletan duten eragina ere handiagotzen du.

Eguzkitako kremen erabilera larruazala UV izpietatik babesteko beharrezkoa da. Krema osatzen duten konposatuen eraginen artean, BP-3aren eragina behar da azpimarratu, hainbat herrialdetan sortu duen eztabaida dela eta. Nahiz eta ikerketa gutxik jasotzen duten zer eragin duen BP-3ak koraletan, konposatu hori duten eguzkitako kremak debekatzeko hainbat arrazoi daude. BP-3ak koraletan toxikotasuna eragiteko duen gaitasuna inguruneko hainbat faktoreren mende dago: erabilitako koral espezie ezberdinak, substantzia toxiko mota, tenperatura, $\mathrm{pHa}$, argia eta pertsona bakoitzaren osasuna. Horregatik, lortutako datuen parekotasuna aintzat hartu behar den arren, faktoreek aldakortasuna eragiten dute.

Lortutako biometaketa- eta biomagnifikazio-balioekin koral-espezieetan ikerketa gehiago egin behar direla ondorioztatu daiteke; konposatuek elikadura-katean zehar migratzeak ekartzen duen guztizko arriskua baloratu ahal izateko.

Gizakion larruazala UV izpietatik babestearen eta itsas ekosistema bizirik mantentzearen arteko oreka lortzea beharrezkoa da. FDAk seguru eta eraginkortzat deskribaturiko konposatuak $\mathrm{ZnO}$ eta $\mathrm{Ti}_{2} \mathrm{O}$ iragazki mineralak dira; hala ere, nanopartikula-tamainan azaltzen direnean, hainbat eragin toxiko dituztela erakutsi dute. Horregatik, geruzarekin estaliz gero, segurtasuna areagotu dezaketela aztertu da. Gainera, agente fotobabesle gisa jokatzen duten antioxidatzaile naturalak gehituz gero, eraginkortasuna eta segurtasuna are gehiago nabarmendu daitezke. Beraz, konposatu horiekin osaturiko formulazioa BP-3a ordezkatzeko aukera izan daiteke. Bukatzeko, MAAen eta konposatu glukosinolatoen zein deribatuen babes-ezaugarriak aproposak diren arren, bi konposatuen konbinaketen arteko eragin sinergiko onuragarriak eta koraletan izan ditzaketen eragin toxikoak aztertzea beharrezkoa da. Konposatuek jatorri naturala duten arren, seguruak diren ala ez bermatzea ezinbestekoa da, eta, beraz, beharrezkoak diren probak egitea.

Oxibentzonak itsas ekosisteman duen toxikotasuna jakinda eta toxikotasun hori saihesteko erabili daitezkeen aukera ezberdinak balioztatuta, lanean zehar aipatutako osagai ezberdin horiek sakonago aztertzeko beharra azpimarratu behar da. Horrez gain, biztanleriak eguzkiarekiko esposiziotik babesteari buruzko informazioa jaso eta ohiturak aldatu beharra azpimarratzen da. Mundu-mailako kontzientziak ekosistemen suntsiketa gelditzea ekar dezake, eta, ondorioz, klima-aldaketa moteltzea. 


\section{BIBLIOGRAFIA}

[1] Agencia de Protección Ambiental de Estados Unidos (EPA). «Información básica sobre los arrecifes de coral». Eskuragarri: https://espanol.epa.gov/espanol/informacion-basica-sobre-los-arrecifes-de-coral 2018ko ekainaren 20an eguneratua.

[2] Agencia de Protección Ambiental de Estados Unidos (EPA). «La importancia de los arrecifes de coral». Eskuragarri: https://espanol.epa.gov/espanol/ la-importancia-de-los-arrecifes-de-coral 2018ko ekainaren 20an eguneratua.

[3] Agencia de Protección Ambiental de Estados Unidos (EPA). «Amenazas para los arrecifes de coral». Eskuragarri: https://espanol.epa.gov/espanol/ amenazas-para-los-arrecifes-de-coral 2018ko ekainaren 20 an eguneratua.

[4] Organización Meteorológica Mundial (OMM) (2013ko irailaren 27a). Comunicado de prensa OMM/PNUMA - El IPCC confirma que el calentamiento de la Tierra seguirá aumentando a causa de la actividad humana y tendrá repercusiones graves en el tiempo, el nivel del mar y el Ártico. Eskuragarri: https://public.wmo.int/es/media/press-release/comunicado-de-prensa-ommpnuma-el-ipcc-confirma-que-el-calentamiento-de-la-tierra

[5] Zachos E, Rosen E (datarik gabea). What sunscreens are best for you - and the planet? Eskuragarri: https://www .nationalgeographic.com/travel/features/sunscreen-destroying-coral-reefs-alternatives-travel-spd/

[6] GABBARD, KIM, Galuteria, Ihara, Nishihara, L. Thielen (2018). Hawaii State Legislature. 30th Legislature, 2019. Relating to water pollution. Eskuragarri: http://www.capitol.hawaii.gov/Archives/measure_indiv_Archives.as px ?billtype $=$ SB\&billnumber $=2571 \&$ year $=2018$

[7] Slijkerman D eta Bol S (datarik gabea). Sunscreen Awareness Bonaire. Moving towards an oxybenzone-free island. BioNews 15 - Content 5-7. Eskuragarri: https://www.dcbd.nl/sites/www .dcbd.nl/files/documents/BioNews-15Sunscreen.pdf

[8] Gonzalez Kotala Z (2019ko ekainaren 26a). UCF research impact: U.S. Virgin Islands Ban Harmful Sunscreens. UCF Today: University of Central Florida. Eskuragarri: https://www.ucf.edu/news/ucf-research-impact-u-s-virginislands-ban-harmful-sunscreens/

[9] The Republic of Palau bans sunscreen chemicals to protect its coral reefs and UNESCO Wold Heritage site (datarik gabea). International Coral Reef Initiative (ICRI). Eskuragarri: https://www.icriforum.org/news/2018/11/republic-palaubans-sunscreen-chemicals-protect-its-coral-reefs-and-unesco-world-herita

[10] Tommy E. Remengesau, Jr. President (2018ko urriaren 25a). Republic of Palau. Signing Statement SB No. 10-135, SD1, HD1 (The Responsible Tourism Education Act of 2018). Eskuragarri: https://www.palaugov.pw/wp-content/ uploads/2018/10/RPPL-No.-10-30-re.-The-Responsible-Tourism-EducationAct-of-2018.pdf

[11] DiNardo, J. C. y Downs, C. A. (2018). Dermatological and environmental toxicological impact of the sunscreen ingredient oxybenzone/benzophenone-3. Journal of Cosmetic Dermatology, 17 (1), 15-19. 
[12] Kim, S., y Choi, K. (2014). Occurrences, toxicities, and ecological risks of benzophenone-3, a common component of organic sunscreen products: A mini-review. Environment International, 70, 143-157.

[13] Huo, W., Cai, P., Chen, M., Li, H., Tang, J., Xu, C., Zhu, D., Tang, W., y Xia, Y. (2016). The relationship between prenatal exposure to BP-3 and Hirschsprung's disease. Chemosphere, 144, 1091-1097.

[14] Danovaro, R., Bongiorni, L., Corinaldesi, C., Giovannelli, D., Damiani, E., Astolfi, P., Greci, L. y Pusceddu, A. (2008). Sunscreens cause coral bleaching by promoting viral infections. Environmental Health Perspectives, 116 (4), 337-340.

[15] Sherwood, V. F., Kennedy, S., Zhang, H., Purser, G. H., y Sheaff, R. J. (2012). Altered UV absorbance and cytotoxicity of chlorinated sunscreen agents. Cutaneous and Ocular Toxicology, 31 (4), 273-279.

[16] Zhang, S., Wang, X., Yang, H., y Xie, Y. F. (2016). Chlorination of oxybenzone. Kinetics, transformation, disinfection byproducts formation, and genotoxicity changes. Chemosphere, 154, 521-527.

[17] Downs, C. A., Kramarsky-Winter, E., Segal, R., Fauth, J., Knutson, S., Bronstein, O., ... Loya, Y. (2016). Toxicopathological Effects of the Sunscreen UV Filter, Oxybenzone (Benzophenone-3), on Coral Planulae and Cultured Primary Cells and Its Environmental Contamination in Hawaii and the U.S. Virgin Islands. Arch Environ Contam Toxicol, 70, 265-288.

[18] Compound Summary, Oxybenzone (s.f). US National Library of Medicine. National Center for Biotechnology Information: PubChem Database. Eskuragarri: https://pubchem.ncbi.nlm.nih.gov/compound/Oxybenzone (2020ko urtarrilaren 18an sartua).

[19] Todo lo que debes saber y cómo podemos acabar con el blanqueamiento de los corales (2019ko apirilaren 23a). Descubre WWF. Eskuragarri: https:// www.worldwildlife.org/descubre-wwf/historias/todo-lo-que-debes-saber-ycomo-podemos-acabar-con-el-blanqueamiento-de-los-corales

[20] Tsui, M. M. P., Lam, J. C. W., Ng, T. Y., Ang, P. O., Murphy, M. B., y Lam, P. K. S. (2017). Occurrence, distribution and fate of organic UV filters in coral communities. Environ. Sci. Technol., Just Accepted Manuscript. Doi: 10.1021/acs.est.6b05211.

[21] What is coral bleaching? National Ocean Service. National Oceanic and Atmospheric Administration US Department of Commerce. Eskuragarri: https://oceanservice.noaa.gov/facts/coral_bleach.html

[22] Gago-Ferrero, P., y Díaz-Cruz, M. S. (2012). An overview of UV-absorbing compounds (organic UV filters) in aquatic biota. Anal Bioanal Chem, 404, 2597-2610.

[23] Peng, X., Fan, Y., Jin, J., Xiong, S., Liu, J., y Tang, C. (2017). Bioaccumulation and biomagnification of ultraviolet absorbents in marine wildlife of the Pearl River Estuarine, South China Sea. Environmental Pollution, 225, 55-65.

[24] Skincare Chemicals and Coral Reefs. National Ocean Service. National Oceanic and Atmospheric Administration US Department of Commerce. 
Eskuragarri: https://oceanservice.noaa.gov/news/sunscreen-corals.html [25] Brausch, J. M., y Rand, G. M. (2011). A review of personal care products in the aquatic environment: Environmental concentrations and toxicity. Chemosphere, 82 (11), 1518-1532.

[26] Muñiz-González, A. B., y Martínez-Guitarte, J. L. (2020). Combined effects of benzophenone-3 and temperature on gene expression and enzymatic activity in the aquatic larvae Chironomus riparius. Science of Total Environment, 698, 134292.

[27] Kranzfelder, P., Anderson, A. M., Egan, A. T., Mazack, J. E., Bouchard,, R. W., Rufer, M. M., y Ferrington, L. C. (2015). Use of Chironomidae (Diptera) Surface-Floating Pupal Exuviae as a Rapid Bioassessment Protocol for Water Bodies. Journal of Visualized Experiments, 101. Doi: 10.3791/52558.

[28] Antoniou, C., Kosmadaki, M. G., Stratigos, A. J., y Katsambas, A. D. (2008). Sunscreens - what's important to know. J. Eur. Acad. Dermatol. Venereol., 22 (9), 1110-1118.

[29] Abid, A. R., Bronisław, M., Pędziński, T. y Shahid, M. (2017). Photo-stability and photo-sensitizing characterization of selected sunscreens' ingredients. $J_{O}$ urnal of Photochemistry and Photobiology A: Chemistry, 332, 241-50.

[30] Manaia, E. B., Kaminski, R. C. K., Corrêa, M. A., y Chiavacci, L. A. (2013). Inorganic UV filters. Brazilian Journal of Pharmaceutical Sciences, 49(2).

[31] Diffey, B. L., Tanner, P. R., Matts, P. J., y Nash, F. J. (2000). In vitro assessment of the broad-spectrum ultraviolet protection of sunscreen products. J Am Acad Dermatol., 43(6), 1024-1035.

[32] Federal Register (2019). Proposed Rules. Food and Drug Administration, 84(38). Eskuragarri: https://www.govinfo.gov/content/pkg/FR-2019-02-26/ pdf/2019-03019.pdf

[33] U.S. EPA. Nanomaterial Case Studies: Nanoscale Titanium Dioxide In Water Treatment And In Topical Sunscreen (Final). U.S. Environmental Protection Agency, Washington, DC, EPA/600/R-09/057F, 2010.

[34] FDA Proposes Sunscreen Regulation Changes (2019ko otsaila). FDA Goverment. Eskuragarri: https://www.fda.gov/media/124654/download

[35] Bernstein, E. F., Sarkas, H. W., Boland, P., y Bouche, D. (2019). Beyond sun protection factor: An approach to environmental protection with novel mineral coatings in a vehicle containing a blend of skincare ingredients. $J$ Cosmet Dermatol, 00, 1-9.

[36] Dunaway, S., Odin, R., Zhou, L., Ji, L., Zhang, Y., y Kadekaro, A. L. (2018). Natural antioxidants: Multiple Mechanisms to Protect Skin From Solar Radiation. Frontiers in Pharmacology, 9, 392 artikulua. Doi: 10.3389/ fphar.2018.00392.

[37] Liu, X., Zhang, R., Shi, H., Li, X., Li, Y., Taha, A., y Xu, C. (2018). Protective effect of curcumin against ultraviolet $\mathrm{A}$ irradiation-induced photoaging in human dermal fibroblasts. Molecular Medicine Reports, 17(5), 7227-7237.

[38] Rigby, C. M., Roy, S., Deep, G., Guillermo-Lagae, R., Jain, A. K., Dhar, D., ... Agarwal, R. (2017). Role of p53 in silibinin-mediated inhibition of ultra- 
violet $\mathrm{B}$ radiation-induced DNA damage, inflammation and skin carcinogenesis. Carcinogenesis, 38(1), 40-50.

[39] Melissa Pandika (2018). Looking to Nature for New Sunscreens. ACS Central Science.

[40] Carpenter, E. L., Le, M. N., Miranda, C. L., Reed, R. L., Stevens, J. F., Indra, A. K., y Ganguli-Indra, G. (2018). Photoprotective Properties of Isothiocyanate and Nitrile Glucosinolate Derivatives From Meadowfoam (Limnanthes alba) Against UVB Irradiation in Human Skin Equivalent. Frontiers in Pharmacology, 9, 477 artikulua.

[41] Recomendación conjunta de: OMS, OMM, PNUMA, ICNIRP (2002). $\mathrm{WHO} / \mathrm{SDE} / \mathrm{OEH} / 02.2$. Índice UV solar mundial. Guía práctica. 
